\title{
Purification and properties of methyl mercaptan oxidase from Thiobacillus thioparus TK-m
}

\author{
W. D. Gould ${ }^{1 *}$ and T. KanagaWA ${ }^{2}$ \\ ${ }^{1}$ CANMET, Department of Energy, Mines and Resources, 555 Booth Street, Ottawa, Ontario K1A OG 1, Canada \\ ${ }^{2}$ Fermentation Research Institute, Agency of Industrial Science and Technology, Tsukuba, Ibaraki 305, Japan
}

(Received 26 March 1991; revised 2 September 1991; accepted 23 September 1991)

\begin{abstract}
Methyl mercaptan (MM)-oxidase was purified to near homogeneity from Thiobacillus thioparus TK-m grown on dimethyl sulphide. The enzyme was a monomer with an $M_{r}$ value of approximately 40000 . It oxidized MM stoichiometrically to formaldehyde, $\mathrm{S}^{2-}$ and $\mathrm{H}_{2} \mathrm{O}_{2}$. The enzyme had a $K_{\mathrm{m}}$ of 31.3 $\mu \mathrm{M}$ for $\mathrm{MM}$. It was also shown to oxidize ethyl mercaptan. MM-oxidase from $T$. thioparus was shown to have some different characteristics from MM-oxidase of Hyphomicrobium EG, such as a higher $K_{m}$, the absence of inhibition by $\mathrm{S}^{2-}$ and the inability to catalyse the oxidation of $\mathrm{S}^{2-}$.
\end{abstract}

\section{Introduction}

Methyl sulphides such as dimethyl sulphide (DMS), dimethyl disulphide (DMDS) and methyl mercaptan (MM) are among the major volatile organic sulphur compounds produced in nature (Andreae \& Raemdonck, 1983; Bremner \& Steele, 1978; Lovelock et al., 1972; Nguyen et al., 1978). Several strains of Hyphomicrobium (de Bont et al., 1981; Suylen \& Kuenen, 1986; Suylen et al., 1986) and Thiobacillus (Kanagawa \& Kelly, 1986; Kanagawa \& Mikami, 1989; Sivela \& Sundman, 1975; Smith \& Kelly, 1988) have been shown to metabolize methyl sulphides.

De Bont et al. (1981) isolated a Hyphomicrobium sp. capable of growth on dimethyl sulphoxide (DMSO) and DMS. They suggested that DMSO metabolism involves an initial reduction of the substrate to DMS which is subsequently oxidized to formaldehyde and MM. MM is further oxidized to formaldehyde and $\mathrm{S}^{2-}$. One of the key reactions in this pathway is the oxidation of MM. Suylen et al. (1987) purified MM-oxidase to near homogeneity from Hyphomicrobium grown on DMSO. This enzyme catalysed the oxidation of $M M$ to formaldehyde and $\mathrm{S}^{2-}$ with the production of $\mathrm{H}_{2} \mathrm{O}_{2}$. Ethyl mercaptan and $\mathrm{S}^{2-}$ were also oxidized by the enzyme, although $\mathrm{S}^{2-}$ was a non-competitive inhibitor for MM oxidation.

T. thioparus TK-m grew on MM, DMS, DMDS and $\mathrm{H}_{2} \mathrm{~S}$ and stoichiometrically oxidized them to $\mathrm{SO}_{4}^{2-}$

Abbreviations: DMS, dimethyl sulphide; DMDS, dimethyl disulphide; DMSO, dimethyl sulphoxide; MM, methyl mercaptan; NEM, $N$-ethyl maleimide.
(Kanagawa \& Mikami, 1989). This strain was found to be very useful for removing those compounds from contaminated air (Tanji et al., 1989). The objectives of this study were to purify and characterize MM-oxidase from $T$. thioparus TK-m.

\section{Methods}

Culture conditions. Cells of $T$. thioparus TK-m were obtained from a continuous culture column $(60 \times 570 \mathrm{~mm})$ to which was added $100 \mathrm{ml}$ of inoculum and $1100 \mathrm{ml}$ of medium C (Kanagawa \& Kelly, 1986) containing: $2 \mathrm{mM}-\mathrm{Na}_{2} \mathrm{~S}_{2} \mathrm{O}_{3}$, trace metal solution $\left(4 \mathrm{ml} \mathrm{l}^{-1}\right)$ and $\mathrm{NH}_{4} \mathrm{Cl}$ $\left(1.8 \mathrm{~g}^{-1}\right)$. The column was run for $3 \mathrm{~d}$ at $25^{\circ} \mathrm{C}$ using $\mathrm{Na}_{2} \mathrm{~S}_{2} \mathrm{O}_{3}$ as a substrate, DMS gas was introduced into the column and then the concentration of DMS was increased as the cells grew. After 1 week, continuous culture $\left(D=0.028 \mathrm{~h}^{-1}\right)$ was begun and this was carried on for $25 \mathrm{~d}$ under aseptic conditions. At regular intervals the cells were harvested by centrifugation, washed with $26 \mathrm{~mm}$-potassium phosphate buffer ( $\mathrm{pH} \mathrm{6.8)}$ and stored at $-80^{\circ} \mathrm{C}$.

Chemicals. Horseradish peroxidase type VI-A, reagents for protein determination and protein standards for $M_{\mathrm{r}}$ determination were all obtained from Sigma. DEAE-Sephacel was obtained from Pharmacia LKB and Bio-Gel P60 from Bio-Rad; SDS-PAGE gels were obtained from Daiichi Pure Chemicals (Tokyo, Japan). $N$-Ethyl maleimide (NEM), 3-methyl-2-benzothiazolinone hydrazone hydrochloride monohydrate and 3-(dimethylamino)benzoic acid were obtained from Wako Chemical Co. (Osaka, Japan). MM gas ( $2 \mathrm{ml}^{\text {and }} 5 \mathrm{ml} \mathrm{l}^{-1}$ of nitrogen) and DMS gas ( $2 \mathrm{ml} \mathrm{l}^{-1}$ of nitrogen) in 401 gas tanks were obtained from Seitetsu Chemical Industries (Osaka, Japan). All other chemicals were of reagent grade.

Purification of $M M$-oxidase. Approximately $1.2 \mathrm{~g}$ (dry wt) of $T$. thioparus TK-m cells were washed with $50 \mathrm{ml} 50 \mathrm{mM}-\mathrm{Tris} / \mathrm{HCl}, \mathrm{pH} \mathrm{8.2}$, centrifuged, suspended in $30 \mathrm{ml} 10 \mathrm{~mm}-\mathrm{Tris} / \mathrm{HCl}, \mathrm{pH} 8.2$, and sonicated five times for $30 \mathrm{~s}$ at full power (200 W) (UD-201; Tomy 
Seiko Co., Tokyo, Japan). The cell suspension was made up to $60 \mathrm{ml}$ with $10 \mathrm{mM}$-Tris $/ \mathrm{HCl}, \mathrm{pH} 8.2$, calcium chloride was added to a final concentration of $2.0 \mathrm{mM}$ and the cell suspension was centrifuged at $20000 \mathrm{~g}$ for $40 \mathrm{~min}$.

The crude extract was made up to $100 \mathrm{ml}$ in $10 \mathrm{mM}-\mathrm{Tris} / \mathrm{HCl}, \mathrm{pH} 8 \cdot 2$, containing a final concentration of $40 \mathrm{mM}-\mathrm{KCl}$. The extract was then eluted through a column $(20 \times 2.5 \mathrm{~cm})$ containing DEAE-Sephacel. The column was then washed with $100 \mathrm{ml}$ of the elution buffer. The eluate plus washing buffer were combined and eluted through a second DEAE-Sephacel column of the same dimensions. The second column was also washed with $100 \mathrm{ml}$ of the elution buffer. The eluate plus washing buffer were combined and concentrated tenfold using an Amicon ultrafiltration unit with a PM10 membrane filter. The extract was made up to $200 \mathrm{ml}$ with $10 \mathrm{mM}-\mathrm{Tris} / \mathrm{HCl}, \mathrm{pH} 8 \cdot 2$, and concentrated tenfold. This procedure was repeated and $10 \mathrm{ml}$ of partially purified extract were obtained; $7 \mathrm{ml}$ of this extract were applied to a gel (BioGel P60) filtration column $(100 \times 2.6 \mathrm{~cm})$ and eluted with $50 \mathrm{~mm}-$ Tris $/ \mathrm{HCl}, \mathrm{pH} 8 \cdot 2$, containing $100 \mathrm{mM}-\mathrm{KCl}$ at a flow rate of $8.0 \mathrm{ml} \mathrm{h}^{-1}$.

$M_{\mathrm{r}}$ and purity check. The $M_{\mathrm{r}}$ of the enzyme was determined by gel permeation chromatography (Bio-Gel P60 gel) and FPLC. FPLC was done using $50 \mathrm{~mm}-\mathrm{Tris} / \mathrm{HCl}$ buffer, $\mathrm{pH} 8 \cdot 2$, containing $200 \mathrm{~mm}-\mathrm{KCl}$ at a flow rate of $0.5 \mathrm{ml} \mathrm{min}^{-1}$ and a Pharmacia Superose- 12 column. The subunit $\boldsymbol{M}_{\mathrm{r}}$ was determined by SDS-PAGE (Laemmli, 1970). Protein was determined by the Lowry procedure.

Enzyme assays. The substrate was prepared by first bubbling nitrogen gas through $10 \mathrm{~mm}$-potassium phosphate buffer, $\mathrm{pH} 7.5$, in a sealed vial for $0.5 \mathrm{~h}$. Then MM (5 ml $\mathrm{l}^{-1}$ in nitrogen) was bubbled through the same buffer for $3.0 \mathrm{~h}$. The MM concentration was determined using a total organic carbon analyser (TOC-500; Shimadzu). MM concentrations between 1.3 and $1.5 \mathrm{mM}$ were consistently obtained by this method. Enzyme assays were done in duplicate by determination of formaldehyde, the initial product of $\mathbf{M M}$ oxidation. A $30 \mathrm{~s}$ assay time was used, the reaction was stopped by addition of an equal volume of $1.3 \%$ perchloric acid and formaldehyde was determined colorimetrically (Nash, 1953). All enzyme assays were done in $50 \mathrm{~mm}$-Tris/ $\mathrm{HCl}, \mathrm{pH} 8.2$, at $25^{\circ} \mathrm{C}$ using $30 \mu \mathrm{g}$ enzyme $\mathrm{ml}^{-1}$ with an initial substrate concentration of $75 \mu \mathrm{M}$. The activity of MM-oxidase towards several other substrates was also measured using an oxygen electrode (Oxygraph-8; Central Kagaku Co., Tokyo, Japan). The assay was done at $30^{\circ} \mathrm{C}$ in a $2.8 \mathrm{ml}$ cell containing $40 \mu \mathrm{g}$ of enzyme and $540 \mathrm{nmol} \mathrm{MM}$ dissolved in $50 \mathrm{mM}-\mathrm{Tris} / \mathrm{HCl}, \mathrm{pH} 8 \cdot 2$. The reaction was initiated by addition of enzyme. The effect of $\mathrm{pH}$ on MM-oxidase activity was determined using $25 \mathrm{~mm}$-citric acid/sodium phosphate buffer over the $\mathrm{pH}$ range 3.0 to 8.0 and $25 \mathrm{~mm}$-glycine/sodium hydroxide buffer over the range 8.6 to 10.6 .

Stoichiometry of MM oxidation. Serum vials $(68.8 \pm 0.6 \mathrm{ml}$ vol. $)$ were soaked in $0.1 \mathrm{M}-\mathrm{HCl}$ for $2 \mathrm{~h}$, washed with distilled water, dried at $105^{\circ} \mathrm{C}$ and then the inside of each vial was coated with phosphoric acid using $150 \mathrm{~mm}-\mathrm{H}_{3} \mathrm{PO}_{4}$ in acetone. To each vial $3.0 \mathrm{ml} 50 \mathrm{~mm}-\mathrm{Tris} / \mathrm{HCl}$ containing $0.2 \mathrm{~mm}$-EDTA, $\mathrm{pH} 8.2$, was added and the vial was sealed with a Teflon-coated rubber stopper which reduced the vial volume by
$0.4 \mathrm{ml}$. To the sealed vials $239 \mathrm{nmol} \mathrm{MM}$ was added by replacing $3.0 \mathrm{ml}$ of head-space gas with $3.0 \mathrm{ml} \mathrm{MM}$ gas $\left(2 \mathrm{ml} \mathrm{1}^{-1}\right.$ of nitrogen) and the vials were shaken at $25^{\circ} \mathrm{C}$ for more than $10 \mathrm{~min}$. The reaction was initiated by injecting $50 \mu \mathrm{l}$ of enzyme solution dissolved in $50 \mathrm{~mm}$ Tris/ $\mathrm{HCl}$ containing $0 \cdot 1 \mathrm{mM}-\mathrm{EDTA}, \mathrm{pH} 8 \cdot 2$, and the vials were shaken at $25^{\circ} \mathrm{C}$. The reaction was terminated by the injection of $0.1 \mathrm{ml} 2.0 \mathrm{M}$ $\mathrm{H}_{2} \mathrm{SO}_{4}$. $\mathrm{MM}$ and $\mathrm{H}_{2} \mathrm{~S}$ in the head-space gas were determined by gas chromatography (Shimadzu GC-14A) (Kanagawa \& Mikami, 1989). The total amount of $\mathrm{MM}$ and $\mathrm{H}_{2} \mathrm{~S}$ in the vial was estimated by comparing the experimental data with concentrations obtained by adding various amounts of $M M$ and $\mathrm{H}_{2} \mathrm{~S}$ to the vials followed by the addition of $\mathrm{H}_{2} \mathrm{SO}_{4}$. Samples $(2 \mathrm{ml})$ of the liquid in the vials were transferred to test-tubes and formaldehyde was determined colorimetrically (Nash, 1953).

To estimate $\mathrm{H}_{2} \mathrm{O}_{2}$ production the sealed serum vial containing the complete reaction mixture was shaken at $25^{\circ} \mathrm{C}$ for $20 \mathrm{~min}$ to complete MM oxidation and $0.6 \mathrm{ml}$ of the liquid was transferred to a test-tube. The $\mathrm{pH}$ was adjusted to 7 by the addition of $12 \mu \mathrm{l} \mathrm{M}-\mathrm{HCl}$ and $\mathrm{H}_{2} \mathrm{O}_{2}$ was determined colorimetrically by the procedure of Ngo \& Lenhoff (1980).

Inhibition of $M M$-oxidase. Various inhibitors were pre-incubated for $20 \mathrm{~min}$ with MM-oxidase. MM-oxidase activity was then assayed (by measurement of formaldehyde production) using $60 \mu \mathrm{g}$ of enzyme in a $2.0 \mathrm{ml}$ reaction mixture at a temperature of $25^{\circ} \mathrm{C}$, a substrate concentration of $75 \mu \mathrm{M}$ and a time duration of $2.0 \mathrm{~min}$.

Induction of MM-oxidase. T. thioparus TK-m was grown at $25^{\circ} \mathrm{C}$ in a glass column $(100 \times 600 \mathrm{~mm})$ to which was added $100 \mathrm{ml}$ of inoculum and 2.51 of medium $\mathrm{C}$ containing $0.8 \mathrm{mM}-\mathrm{Na}_{2} \mathrm{~S}_{2} \mathrm{O}_{3}$. The $\mathrm{pH}$ of the culture was maintained at 6.7 by addition of $0.4 \mathrm{M}-\mathrm{K}_{2} \mathrm{CO}_{3}$. When $0.4 \mathrm{M}$ $\mathrm{K}_{2} \mathrm{CO}_{3}$ was added, twice the volume of $0.2 \mathrm{M}-\mathrm{Na}_{2} \mathrm{~S}_{2} \mathrm{O}_{3}$ was also added simultaneously. After $4 \mathrm{~d}$ addition of $\mathrm{Na}_{2} \mathrm{~S}_{2} \mathrm{O}_{3}$ was stopped, the culture was made up to 3.11 by addition of distilled water and then DMS gas ( $2 \mathrm{ml} \mathrm{l}^{-1}$ of nitrogen) was added at a flow rate of $20 \mathrm{ml} \mathrm{min}^{-1}$. The total volume of $0.2 \mathrm{M}-\mathrm{Na}_{2} \mathrm{~S}_{2} \mathrm{O}_{3}$ added was $200 \mathrm{ml}$. At various times $100 \mathrm{ml}$ of the culture was removed and centrifuged. The harvested cells were washed once and suspended in $3 \mathrm{ml} 50 \mathrm{mM}$-Tris/ $\mathrm{HCl}, \mathrm{pH} 8.2$. The crude extracts of the cells were sonicated, prepared for SDS-PAGE and the MM-oxidase activity was measured.

\section{Results and Discussion}

\section{Purification and physical characteristics of $M M$-oxidase}

A typical purification procedure is shown in Table 1. The crude extract showed a lower total activity than the eluate of the DEAE-Sephacel column, probably due to the presence of inhibitors contained in the crude extract. MM-oxidase activity readily elutes through the DEAESephacel column at $\mathrm{pH} 8 \cdot 2$, which results in an effective

Table 1. Purification of methyl mercaptan oxidase

\begin{tabular}{lcccccr}
\hline \hline & $\begin{array}{c}\text { Total } \\
\text { units }\end{array}$ & $\begin{array}{c}\text { Total } \\
\text { protein } \\
(\mathrm{ml})\end{array}$ & $\begin{array}{c}\text { Specific } \\
\text { activity } \\
\left(\mu \mathrm{mol} \text { min }^{-1}\right)\end{array}$ & $\begin{array}{c}{\left[\mu \text { min }^{-1}\right.} \\
\left.(\mathrm{mg} \text { protein })^{-1}\right]\end{array}$ & $\begin{array}{c}\text { Purification } \\
\text { ratio }\end{array}$ & $\begin{array}{c}\text { Yield } \\
(\%)\end{array}$ \\
\hline Crude extract & 60 & 33.3 & 794 & 0.042 & 1 & 100 \\
DEAE-Sephacel & 10 & 41.8 & 39.8 & 1.05 & 25 & 126 \\
Gel filtration & 21 & 21.6 & 17.0 & 1.27 & 30 & 65 \\
\hline \hline
\end{tabular}




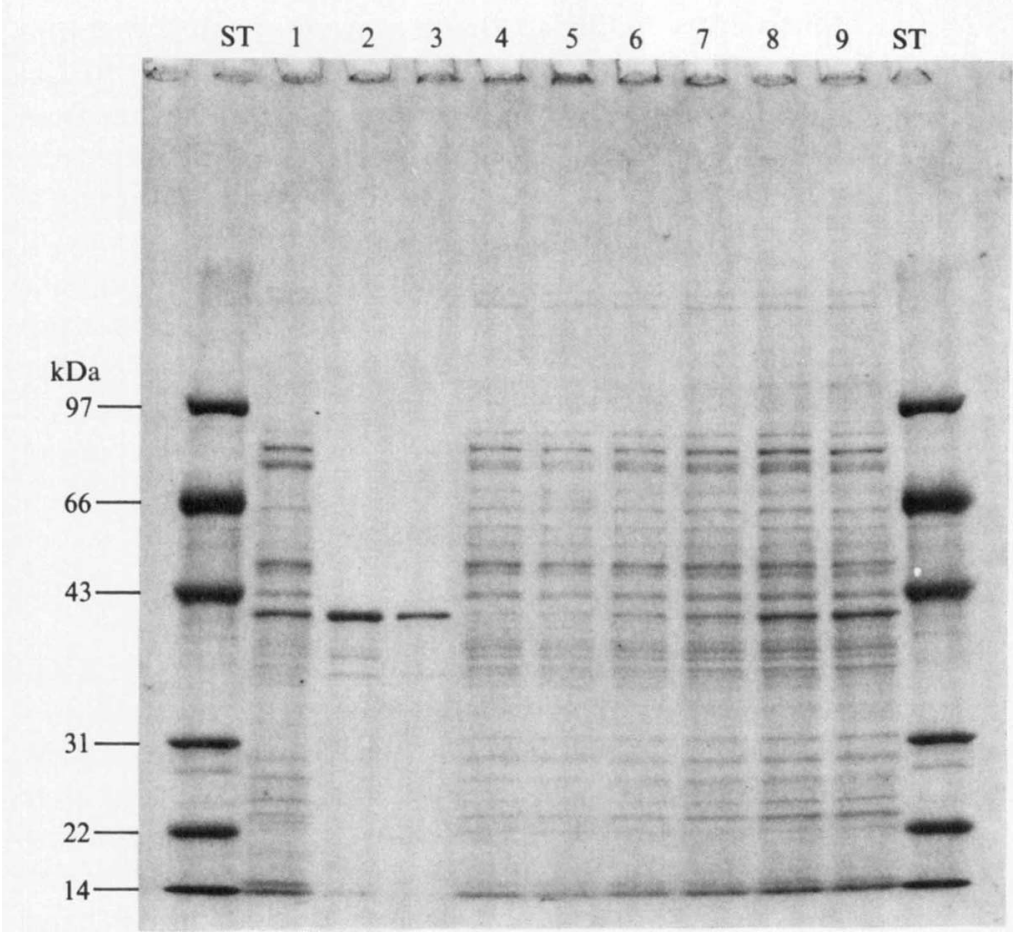

Fig. 1. SDS-PAGE of extracts of $T$. thioparus TK-m. ST. $M_{\mathrm{r}}$ standards. Lanes 1-3 show the purification steps. Lane 1, crude extract; lane 2, DEAESepharose; lane 3, gel filtration. Lanes 4-9 show the induction of $\mathrm{MM}$-oxidase by changing the substrate from $\mathrm{Na}_{2} \mathrm{~S}_{2} \mathrm{O}_{3}$ to DMS. Lane 4 , cells grown on $\mathrm{Na}_{2} \mathrm{~S}_{2} \mathrm{O}_{3}$; lane $5,2.5 \mathrm{~h}$ after changing to DMS; lane $6,5.0 \mathrm{~h}$; lane $7,7.5 \mathrm{~h}$; lane $8,20 \mathrm{~h}$; lane $9,44 \mathrm{~h}$. and convenient initial purification step that also provides a high yield of the enzyme. One major difference between the enzymes obtained from the two different sources is that $T$. thioparus/MM-oxidase did not bind to DEAE-Sephacel whereas the enzyme from Hyphomicrobium did (Suylen et al., 1987). This suggests that there are significant differences in the surface charges of the two enzymes. The enzyme co-eluted with carbonic anhydrase on the Bio-Gel P60 column indicating an $M_{\mathrm{r}}$ value of approximately 29000 . This result was also confirmed by FPLC. On SDS-PAGE the enzyme proved to be nearly homogeneous with a subunit $M_{\mathrm{r}}$ of approximately 40000 (Fig. 1). The higher $M_{\mathrm{r}}$ value obtained by SDS-PAGE compared to those obtained by FPLC and gel filtration is unusual. The low surface charge of the enzyme from $T$. thioparus may be due to it having a hydrophobic surface which results in hydrophobic interactions during chromatography which would increase the retention time of the enzyme. In spite of these conflicting results it appears that the enzyme is a monomer. The $M_{\mathrm{r}}$ value of 40000 for MM-oxidase from T. thioparus is in the same range as the value of 40-50000 reported for MM-oxidase from Hyphomicrobium EG (Suylen et al., 1987). Maximum enzyme activity was observed between the $\mathrm{pH}$ values of 8.0 and 9.6. The $K_{\mathrm{m}}$ of MM-oxidase at $\mathrm{pH} 8.2$ was calculated to be $31.3 \mu \mathrm{M}$ and substrate inhibition of the enzyme at high $M M$ concentrations was observed. The $K_{\mathrm{m}}$ value of $31.3 \mu \mathrm{M}$ for MM-oxidase from $T$. thioparus is significantly higher than the value of $10 \mu \mathrm{M}$ reported for the enzyme from Hyphomicrobium EG. However, the enzyme from both sources appears to be inhibited by high substrate concentrations.

\section{Stoichiometry}

MM was converted to $\mathrm{H}_{2} \mathrm{~S}$ stoichiometrically (Table 2). The reaction was completed within 20 min. The production of formaldehyde coincided with the production of $\mathrm{H}_{2} \mathrm{~S}$ and $\mathrm{H}_{2} \mathrm{O}_{2}$ was also detected in the solution. No oxidation of $\mathrm{S}^{2-}$ by $\mathrm{MM}$-oxidase was observed during the stoichiometry experiment (Table 2). The recovery of formaldehyde was $71-78 \%$ and that of the $\mathrm{H}_{2} \mathrm{O}_{2}$ was $60 \%$ if the enzyme catalysed the following reaction:

$$
\mathrm{CH}_{3} \mathrm{SH}+\mathrm{O}_{2}+\mathrm{H}_{2} \mathrm{O} \rightarrow \mathrm{H}_{2} \mathrm{~S}+\mathrm{HCHO}+\mathrm{H}_{2} \mathrm{O}_{2}
$$

Table 2. Stoichiometry of $M M$ oxidation

MM (239 $\mathrm{nmol})$ was added to $3.0 \mathrm{ml}$ of reaction mixture.

\begin{tabular}{cccc}
\hline \hline $\begin{array}{c}\text { Time } \\
(\mathrm{min})\end{array}$ & $\begin{array}{c}\mathrm{MM} \\
(\mathrm{nmol})\end{array}$ & $\begin{array}{c}\mathrm{H}_{2} \mathrm{~S} \\
(\mathrm{nmol})\end{array}$ & $\begin{array}{c}\text { Formaldehyde } \\
(\mathrm{nmol})\end{array}$ \\
\hline 0 & 231 & 0 & 0 \\
2 & 177 & 51 & 44 \\
4 & 123 & 115 & 88 \\
6 & 89 & 153 & 117 \\
8 & 76 & 166 & 126 \\
10 & 57 & 194 & 142 \\
20 & 0 & 223 & 183 \\
\hline \hline
\end{tabular}




\section{Substrate specificity of $M M$-oxidase}

Oxygen consumption occurred in the presence of both MM and ethyl mercaptan but no activity was observed when either methylamine or methanol were used as substrates. Oxygen consumption equivalent to $90 \%$ of the added $\mathbf{M M}$ occurred after the enzyme had been incubated with the substrate for $10 \mathrm{~min}$. The consumption of oxygen concurrent with the oxidation of $\mathrm{MM}$ to $\mathrm{S}^{2-}$, formaldehyde and $\mathrm{H}_{2} \mathrm{O}_{2}$ and the stoichiometry of the reaction are consistent with the behaviour of $\mathrm{MM}$ oxidase. Oxygen uptake experiments indicate that MMoxidase from $T$. thioparus is specific for mercaptans with no activity towards amines or alcohols which has also been observed for the enzyme from Hyphomicrobium sp. $\mathrm{H}_{2} \mathrm{~S}$, which is also a substrate for the enzyme from

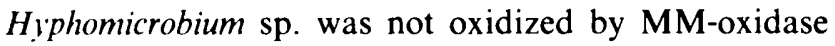
from $T$. thioparus.

\section{Effect of inhibitors on $M M$-oxidase activity}

Methylamine and $\mathrm{S}^{2-}$ had no effect on MM-oxidase activity (Table 3). However, mercaptoethanol, ethyl mercaptan, cyanide and ammonium salts were shown to inhibit the enzyme. MM-oxidase was also inhibited by NEM, but with the exception of $\mathrm{Cu}^{2+}$, metal ions had no effect on the enzyme. The differences in the magnitude of inhibition by various inhibitors of MM-oxidase from the two sources implies that there may be differences in the structure of the active site between the two enzymes. Another difference between the enzyme from the two different sources is the lack of inhibition by one of the main products, $\mathrm{S}^{2-}$. The lack of inhibition by $\mathrm{S}^{2-}$ is also

\section{Table 3. Sensitivity of $M M$-oxidase from $T$. thioparus} towards various known enzyme inhibitors

In the absence of any inhibitor. MM-oxidase activity was $23 \mathrm{nmol}$ MM oxidized $\mathrm{ml}^{-1} \mathrm{~min}^{-1}$

\begin{tabular}{lccc}
\hline \hline Compound & Inhibition & Concn (mM) & Inhibition (\%) \\
\hline Mercaptoethanol & + & $0 \cdot 5$ & 53 \\
Ethyl mercaptan & + & $1 \cdot 7$ & 75 \\
Methylamine & - & $1 \cdot 0$ & - \\
DMS & - & $1 \cdot 0$ & - \\
$\mathrm{CH}_{3} \mathrm{OH}$ & - & $100 \cdot 0$ & - \\
$\mathrm{S}^{2-}$ & - & $1 \cdot 0$ & - \\
$\mathrm{Na}_{2} \mathrm{~S}_{2} \mathrm{O}_{3}$ & - & $5 \cdot 0$ & - \\
$\left(\mathrm{NH}_{4}\right)_{2} \mathrm{SO}_{4}$ & + & 10 & 53 \\
$\mathrm{NH}_{4} \mathrm{Cl}$ & + & 10 & 53 \\
$\mathrm{~K}_{2} \mathrm{SO}_{4}$ & - & 50 & - \\
$\mathrm{KCN}$ & + & $0 \cdot 5$ & 58 \\
$\mathrm{EDTA}_{\mathrm{NEM}}$ & - & $1 \cdot 0$ & - \\
$\mathrm{CuSO}$ & + & $0 \cdot 1$ & 64 \\
$\mathrm{CdCl}_{2}$ & + & $0 \cdot 1$ & 55 \\
$\mathrm{ZnSO}_{4}$ & - & $1 \cdot 0$ & - \\
$\mathrm{NiSO}_{4}$ & - & 1.0 & - \\
\hline \hline
\end{tabular}

consistent with the fact that the enzyme from $T$. thioparus completely oxidizes MM whereas approximately $50 \%$ of the added substrate is oxidized by the enzyme from Hyphomicrobium sp. The inhibition of enzyme activity by NEM is consistent with the presence of an -SH group at the active site; however the lack of inhibition by most of the metal ions tested is not consistent with the involvement of an-SH group in catalysis. NEM has also been shown to react with $\alpha$-amino functional groups (Plapp, 1982). Thus, our studies also have not yet provided definitive evidence for the prosthetic groups of MM-oxidase.

\section{Induction of $M M$-oxidase activity}

The crude extract obtained from cells grown on $\mathrm{Na}_{2} \mathrm{~S}_{2} \mathrm{O}_{3}$ had little MM-oxidase activity. When the substrate was changed from $\mathrm{Na}_{2} \mathrm{~S}_{2} \mathrm{O}_{3}$ to DMS, the MM-oxidase activity increased 1.6-, 2.4-, 3.9-, 9.4- and 12-fold after $2 \cdot 5,5 \cdot 0,7 \cdot 5,20$ and $44 \mathrm{~h}$ respectively. The corresponding protein band on SDS-PAGE increased in size after the addition of DMS (Fig. 1). The MM-oxidase protein band after $20 \mathrm{~h}$ induction was almost the same size as the band for DMS-grown cells. Thus MM-oxidase activity is inducible.

We thank Dr Y. Kamagata of the Fermentation Research Institute for his invaluable advice in the enzyme purification work.

\section{References}

Andreae, M. O. \& Raemdonck, H. (1983). Dimethyl-sulphide in the surface ocean and the marine atmosphere: a global view. Science 221, 744-747.

De Bont, J. A. M., van Dijken, J. P. \& Harder, W. (1981). Dimethyl sulphoxide and dimethyl sulphide as a carbon, sulphur and energy source for growth of Hyphomicrobium S. Journal of General Microbiology 127, 315-323.

Bremner, J. M. \& Steele, C. G. (1978). Role of microorganisms in the atmospheric sulfur cycle. Advances in Microbial Ecology 2, 155-201.

Kanagawa, T. \& Kelly, D. P. (1986). Breakdown of dimethyl sulphide by mixed cultures and by Thiobacillus thioparus. FEMS Microbiology Letters 34, 13-19.

Kanagawa, T. \& MiKami, E. (1989). Removal of methanethiol, dimethyl sulphide, dimethyl disulphide, and hydrogen sulphide from contaminated air by Thiobacillus thioparus TK-m. Applied and Environmental Microbiology 55, 555-558.

LAEMMLI, U. K. (1970). Cleavage of structural proteins during the assembly of the head of bacteriophage T4. Nature, London 227, 680685 .

Lovelock, J. E., Maggs, R. J. \& Rasmussen, R. A. (1972). Atmospheric dimethyl-sulphide and the natural sulphur cycle. Nature, London 237, 452-453.

NaSH, T. (1953). The colorimetric estimation of formaldehyde by means of the Hantsch reaction. Biochemical Journal 55, 416-421.

NGo, T. T. \& LENhofF, H. M. (1980). A sensitive and versatile chromogenic assay for peroxidase and peroxidase coupled reactions. Analytical Biochemistry 105, 389-397.

Nguyen, B. C., Gaudry, A., Bonsang, B. \& Lambert, G. (1978). Reevaluation of the role of dimethyl-sulphide in the sulphur budget. Nature, London 275, 637-639. 
PlapP, B. V. (1982). Application of affinity labelling for studying structures and function of enzymes. Methods in Enzymology 87, 469 499.

Sivela, S. \& Sundman, V. (1975). Demonstration of Thiobacillus-type bacteria which utilize methyl sulfides. Archives of Microbiology 103, 303-304.

Smith, N. A. \& Kelly, D. P. (1988). Isolation and physiological characterization of autotrophic sulphur bacteria oxidizing dimethyl disulphide as sole source of energy. Journal of General Microbiology 134, 1407-1417.

Suylen, G. M. H. \& Kuenen, J. G. (1986). Chemostat enrichment and isolation of Hyphomicrobium EG. A dimethyl-sulphide oxidizing methylotroph and reevaluation of Thiobacillus MS1. Antonie van Leeuwenhoek 52, 281-293.
Suylen, G. M. H., Stefess, G. C. \& Kuenen, J. G. (1986). Chemolithotrophic potential of a Hyphomicrobium species, capable of growth on methylated sulphur compounds. Archives of Microbiology 146, 192-198.

Suylen, G. M. H., Large, P. J., van Dijken, J. P. \& Kuenen, J. G. (1987). Methyl mercaptan oxidase, a key enzyme in the metabolism of methylated sulphur compounds by Hyphomicrobium EG. Journal of General Microbiology 133, 2989-2997.

Tanj, Y., Kanagawa, T. \& Mikami, E. (1989). Removal of dimethyl sulfide, methyl mercaptan, and hydrogen sulfide by immobilized Thiohacillus thioparus TK-m. Journal of Fermentation and Bioengineering 67, 280-285. 